\title{
Production of Bio Hydrofined Diesel, Jet Fuel, and Carbon Monoxide from Fatty Acids Using a Silicon Nanowire Array-Supported Rhodium Nanoparticle Catalyst under Microwave Conditions
}

\author{
Heeyoel Baek, ${ }^{+}$Keiichiro Kashimura, ${ }^{\S}$ Takashi Fujii, ${ }^{\S}$ Shuntaro Tsubaki, ${ }^{\Pi}$ Yuji Wada, ${ }^{\Pi}$ Shigenori Fujikawa, ${ }^{\Phi}$ \\ Takuma Sato, ${ }^{\dagger}$ Yasuhiro Uozumi, ${ }^{+\ddagger}$ Yoichi M. A. Yamada ${ }^{+*}$
}

${ }^{+}$RIKEN Center for Sustainable Resource Science, Wako, Saitama 351-0198, Japan

${ }^{\S}$ Faculty of Engineering, Chubu University, Kasugai, Aichi 487-8501, Japan

п School of Materials and Chemical Technology, Tokyo Institute of Technology, Meguro, Tokyo 152-8550, Japan

I International Institute for Carbon-Neutral Energy Research (WPI-I²CNER), Kyushu University, Fukuoka 819-0395, Japan

${ }^{\ddagger}$ Institute for Molecular Science, Okazaki, Aichi 444-8787, Japan

ymayamada@riken.jp

Table of Contents

1. General Information

2. Preparation of a SiNA-Stabilized Rh Nanoparticle Catalyst

3. Preparation of a SiNA-Stabilized Metal Nanoparticle Catalysts

4. ICP-MS Analysis

5. General Procedure for the Decarboxylation of Carboxylic acids

6. Catalyst Reuse Experiments

7. Catalyst Reuse Experiments with Pivalic Anhydride

8. General Procedure for the Decarbonylation of an Aldehyde 
9. Characterization of the Products

10. Reference 


\section{General Information:}

All reagents, purchased from TCI, Aldrich, Wako, MERCK, and Fluka, were used without further purification. Water was deionized with a Millipore system as a Milli-Q grade. NMR spectra were recorded with JEOL JNM-AL500 spectrometer $(500 \mathrm{MHz})$ in $\mathrm{CDCl}_{3}$ at $25{ }^{\circ} \mathrm{C}$. For ${ }^{1} \mathrm{H} \mathrm{NMR}$ spectra, proton chemical shifts $(\delta)$ are given in $\mathrm{ppm}$ relative to tetramethylsilane $(0.00 \mathrm{ppm})$ in $\mathrm{CDCl}_{3}$. Multiplicities are indicated by s (singlet), $\mathrm{d}$ (doublet), $\mathrm{t}$ (triplet), $\mathrm{m}$ (multiplet), and br (broad). For ${ }^{13} \mathrm{C}$ NMR spectra, carbon chemical shifts were internally referenced to the deuterated solvent signal of $\mathrm{CDCl}_{3}$ $(77.0 \mathrm{ppm})$.

TEM/EDX analysis was performed on a JEOL JEM-2100F/JED-2300T. SEM/EDX images were obtained on a JEOL JSM6330F/JEOL JED-2200 or Hitachi TS3030Plus/Bruker nanoGmbH Quantax 70. Inductively coupled plasma mass spectrometer (ICP-MS) was performed on a Perkin Elmer Nexion ${ }^{\mathrm{TM}}$ 300D. Inductively coupled plasma atomic emission spectrometry (ICP-AES) was performed on a Shimadzu ICPS-8100 equipment. The GC-MS was measured by an Agilent 7890A/JEOL JMS-T100GC equipped with a capillary column (IL-60, $0.25 \mathrm{~mm}$ i.d. x $30 \mathrm{~m}$ ). The GC was measured by an Agilent 6850 with a capillary column (DB-WAX, $0.25 \mathrm{~mm}$ i.d. $\times 30 \mathrm{~m}, \mathrm{HP}-1,0.18 \mathrm{~mm}$ i.d. $\times 20 \mathrm{~m}$ ). The GC was measured by an Agilent 7890 equipped with a micro packed column (SHINCARBON ST 80/100, $1.0 \mathrm{~mm}$ i.d. $x 2.0 \mathrm{~m}$ ). XPS spectra were measured with an VG ESCALA 250 spectrometer (Thermo Fisher Scientific K.K.). Microwave reaction was performed on a CEM Discover-SP or Discover System and Microwave Reactor (Ryowa Electronics Co., Ltd.) equipped with a cylindrical cavities ( $E$-field; $\mathrm{TM}_{010}$, $H$-field $\mathrm{TM}_{110}$ ). TLC analysis was performed on Merck silica gel 60 F254. Flash column chromatography was carried out on silica gel (Wakogel C-200). 


\section{Preparation of a SiNA-Stabilized Rh Nanoparticle Catalyst}

A boron doped p-type Si (100) wafer $\left(0.1-100 \Omega \cdot \mathrm{cm} ; \Phi=2\right.$ inch; $\left.1.5 \mathrm{~g} ; \mathrm{S}_{\mathrm{BET}} 4 \mathrm{~cm}^{2} / \mathrm{cm}^{2}(\mathrm{Kr})\right)$ was immersed in a mixture of conc. $95 \% \mathrm{H}_{2} \mathrm{SO}_{4}$ and $30 \% \mathrm{H}_{2} \mathrm{O}_{2}(15 \mathrm{~mL}: 5 \mathrm{~mL}, \mathrm{v} / \mathrm{v})$ for $15 \mathrm{~min}$., and then, washed with $\mathrm{H}_{2} \mathrm{O}$ and dried with $\mathrm{N}_{2}$ blow. The washed $\mathrm{Si}$ wafer was treated with $5 \%$ aqueous $\mathrm{HF}$ (10 $\mathrm{mL}$ ) for 3 min, washed with $\mathrm{H}_{2} \mathrm{O}$, dried with $\mathrm{N}_{2}$ blow. One side of Si wafer was masked with an urethane mask sheet (Kokuyo, Co. Ltd). Masked Si wafer was placed into a mixture of 46\% HF (15 mL) and $\mathrm{AgNO}_{3}$ (53.2 mg) in $\mathrm{H}_{2} \mathrm{O}(47.6 \mathrm{~mL})$, which was slowly stirred for $1 \mathrm{~min}$. The $\mathrm{Ag}$-coated Si wafer was washed with $\mathrm{H}_{2} \mathrm{O}$, and dried with $\mathrm{N}_{2}$ blow. The urethane mask sheet was pealed off. The Ag-coated Si wafer was placed into a mixture of $46 \% \mathrm{HF}(4.0 \mathrm{~mL})$ and $30 \% \mathrm{H}_{2} \mathrm{O}_{2}(0.9 \mathrm{~mL})$ in $\mathrm{H}_{2} \mathrm{O}(19.0 \mathrm{~mL})$ at $60{ }^{\circ} \mathrm{C}$ for 3 min, and Si wafer was washed with $\mathrm{H}_{2} \mathrm{O}$ and dried with $\mathrm{N}_{2}$ blow. The etched Si wafer was immersed twice in $50 \%$ aqueous $\mathrm{HNO}_{3}(30 \mathrm{~mL})$ for 3 min, washed with $\mathrm{H}_{2} \mathrm{O}$, dried with $\mathrm{N}_{2}$ blow to give the Si nanowire array (SiNA). After SiNA was placed into $5 \%$ aqueous $\mathrm{HF}(10 \mathrm{~mL})$ for $1 \mathrm{~min}$, washed with $\mathrm{H}_{2} \mathrm{O}$, dried with $\mathrm{N}_{2}$ blow, it was immersed in a mixture of $50 \mathrm{mM}$ aqueous $\mathrm{RhCl}_{3} \cdot 3 \mathrm{H}_{2} \mathrm{O}(4.5 \mathrm{~mL})$ and acetone $(1.5 \mathrm{~mL})$ for 5 min. The Si wafer was washed with $\mathrm{H}_{2} \mathrm{O}$ and acetone, and dried with $\mathrm{N}_{2}$ blow to give SiNA-stabilized Rh nanoparticle catalyst (SiNA-Rh). The loading of Rh was determined by ICP-MS.

\section{Preparation of a SiNA-Stabilized Metal Nanoparticle Catalysts}

\section{3-1. Monometallic Catalyst (SiNA-Pd and SiNA-Pt)}

Prepared SiNA was placed into 5\% aqueous HF $(10 \mathrm{~mL})$ for 1 min and washed with $\mathrm{H}_{2} \mathrm{O}$ and dried with $\mathrm{N}_{2}$ blow. It was immersed in each mixture of $50 \mathrm{mM}$ aqueous metal solution (in $4.5 \mathrm{~mL}$ ) and acetone $(1.5 \mathrm{~mL})$ for $5 \mathrm{~min}$. The $\mathrm{Si}$ wafer was washed with $\mathrm{H}_{2} \mathrm{O}$ and acetone, and dried with $\mathrm{N}_{2}$ blow to give SiNA-stabilized metal nanoparticle catalyst. The metal salts were used in $\mathrm{K}_{2} \mathrm{PtCl}_{4}$ and $\mathrm{K}_{2} \mathrm{PdCl}_{4}$.

XAFS experiment of Rh K-edge (23.2 keV) was measured at BL14B2, SPring-8 (JASRI), Harima, Japan. The XAFS data processing was performed using Demeter software package[a] and FEFF6 code[b]. The spectra of $\mathrm{Rh}$ foil and $\mathrm{Rh}_{2} \mathrm{O}_{3}$ were measure in transmission mode. The catalyst sample was measured in fluorescent yield mode using 19-element SSD with grazing incident angle geometry.

Ref.

[a] B. Ravel, M. Newville, J. Synchrotron Rad. 2005, 12, 537-541. 


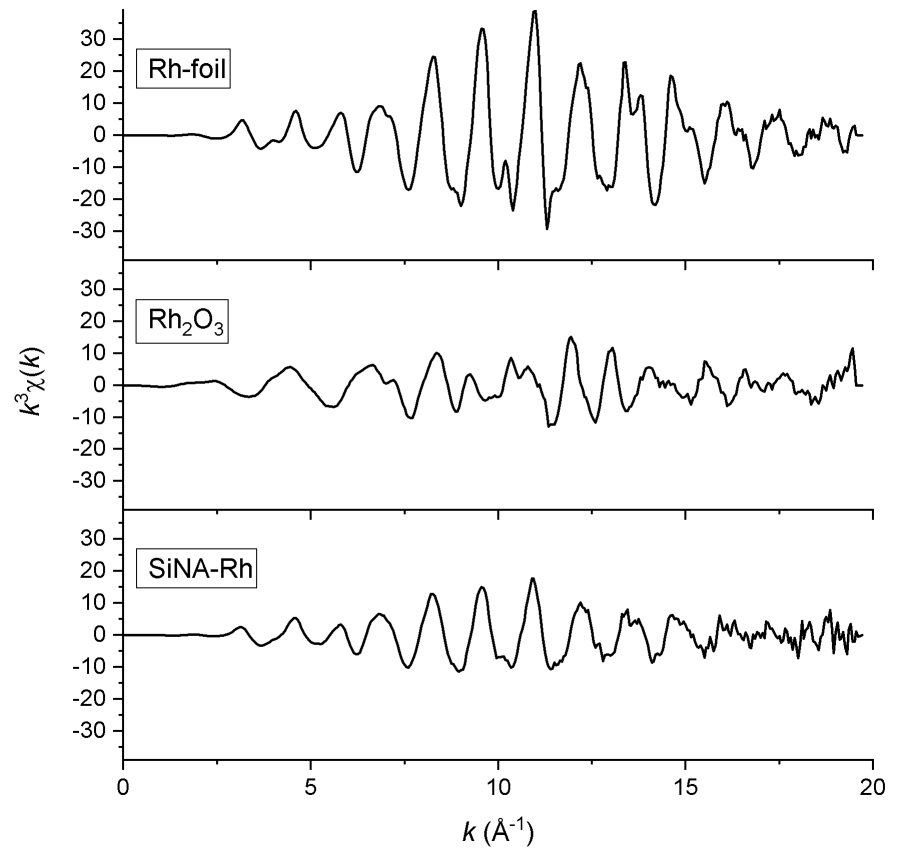

Figure S1. Rh K-edge $k^{3}$-weighted EAXAFS of $R h$ foil, $R h_{2} \mathrm{O}_{3}$, and SiNA-Rh.

\section{3-2. Bimetallic Catalyst (SiNA-PdPt, SiNA-PdRh, SiNA-PdRu, and SiNA-PdIr)}

Prepared SiNA was placed into $5 \%$ aqueous $\mathrm{HF}(10 \mathrm{~mL})$ for 1 min and washed with $\mathrm{H}_{2} \mathrm{O}$ and dried with $\mathrm{N}_{2}$ blow. It was immersed in the mixture of $25 \mathrm{mM}$ aqueous metal solution and $25 \mathrm{mM}$ aqueous metal solution (in total $4.5 \mathrm{~mL}$ ) and acetone $\left(1.5 \mathrm{~mL}\right.$ ) for $5 \mathrm{~min}$. The $\mathrm{Si}$ wafer was washed with $\mathrm{H}_{2} \mathrm{O}$ and acetone, and dried with $\mathrm{N}_{2}$ blow to give SiNA-stabilized metal nanoparticle catalyst. $\mathrm{K}_{2} \mathrm{PtCl}_{4}, \mathrm{~K}_{2} \mathrm{PdCl}_{4}, \mathrm{RuCl}_{3} \cdot \mathrm{nH}_{2} \mathrm{O}$, and $\mathrm{IrCl}_{3} \cdot \mathrm{H}_{2} \mathrm{O}$ were used as metal sources. The loading of each metal was determined by ICP-MS.

\section{3-3. Rhodium Nanoparticle Supported on Porous Silicon Powder $(\mathrm{Rh} / \mathrm{Si})^{1,2}$}

Silicon powder ( $1 \mathrm{~g}$, High Purity Chemical, $99.9 \%$ purity, $<75 \mathrm{~mm}$ ) was placed into the $46 \% \mathrm{HF}(8 \mathrm{~mL})$ and $70 \% \mathrm{HNO}_{3}(2 \mathrm{~mL})$ in $\mathrm{H}_{2} \mathrm{O}(90 \mathrm{~mL})$ and stirred at room temperature for 10 minutes. The silicon powder was filtrated with $\mathrm{H}_{2} \mathrm{O} 500 \mathrm{~mL}$ ) and dried at room temperature for $12 \mathrm{~h}$. Pretreated silicon powder (PSi, $0.5 \mathrm{~g})$ was dispersed in $0.1 \mathrm{M} \mathrm{HF}(100 \mathrm{~mL})$ and stirred for 5 minutes. After $50 \mathrm{mM}$ aqueous $\mathrm{RhCl}_{3} \cdot 3 \mathrm{H}_{2} \mathrm{O}$ solution $(5 \mathrm{~mL})$ was added to PSi solution and stirred for 10 minutes, the PSi was filtrated 
with $\mathrm{H}_{2} \mathrm{O}(500 \mathrm{~mL})$ and dried under vacuum to give PSi-supported $\mathrm{Rh}$ nanoparticle catalyst $(\mathrm{Rh} / \mathrm{Si}, 87 \%$ yield). The loading of Rh was determined by ICP-AES.
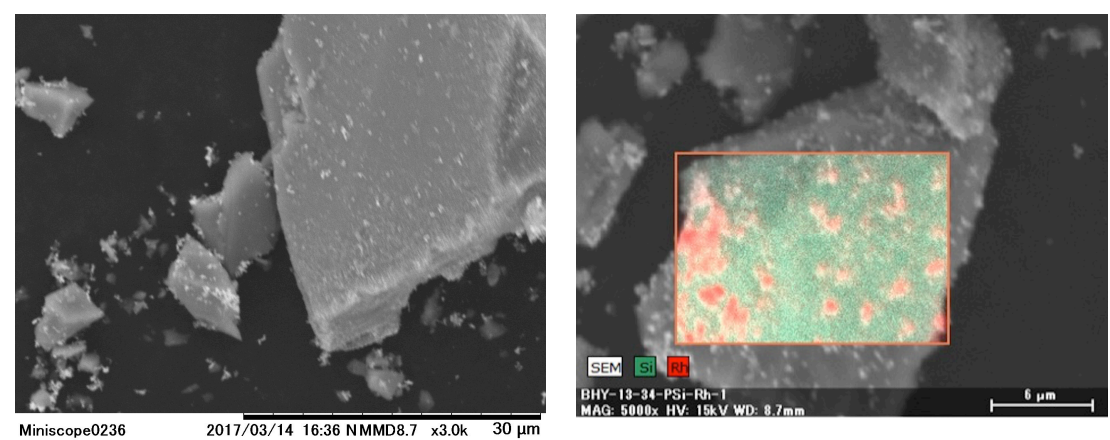

Figure S2. SEM/EDX images of Rh/Si

\section{3-4. Preparation of a Rh Catalyst on Flat Silicon Wafer (Rh/Flat $\mathrm{Si})$}

A boron doped p-type Si (100) wafer (0.1-100 $\Omega \cdot \mathrm{cm} ; \Phi=2$ inch; $\left.1.5 \mathrm{~g} ; \mathrm{S}_{\mathrm{BET}} 4 \mathrm{~cm}^{2} / \mathrm{cm}^{2}(\mathrm{Kr})\right)$ was immersed in a mixture of conc. $95 \% \mathrm{H}_{2} \mathrm{SO}_{4}$ and $30 \% \mathrm{H}_{2} \mathrm{O}_{2}(15 \mathrm{~mL}: 5 \mathrm{~mL}, \mathrm{v} / \mathrm{v})$ for $15 \mathrm{~min}$., and then, washed with $\mathrm{H}_{2} \mathrm{O}$ and dried with $\mathrm{N}_{2}$ blow. The washed Si wafer was placed into a mixture of $46 \% \mathrm{HF}$ ( 15 $\mathrm{mL}$ ) and $\mathrm{RhCl}_{3} \cdot 3 \mathrm{H}_{2} \mathrm{O}(83.0 \mathrm{mg})$ in $\mathrm{H}_{2} \mathrm{O}(47.6 \mathrm{~mL})$, which was slowly stirred for $5 \mathrm{~min}$. The $\mathrm{Rh}$ nanoparticles supported on $\mathrm{Si}$ wafer was washed with $\mathrm{H}_{2} \mathrm{O}$, acetone and dried with $\mathrm{N}_{2}$ blow. The loading of Rh was determined by ICP-MS.

\section{ICP-MS Analysis}

\section{4-1. Metal Loading of SiNA-MNPs}

\begin{tabular}{|c|l|l|}
\hline Entry & Catalysts & Metal loadings \\
\hline 1 & SiNA-Rh & $4.32 \mu \mathrm{mol} / \mathrm{g}$ \\
\hline 2 & SiNA-Pd & $14.0 \mu \mathrm{mol} / \mathrm{g}$ \\
\hline 3 & SiNA-Pt & $6.07 \mu \mathrm{mol} / \mathrm{g}$ \\
\hline 4 & SiNA-Pd $0.65 \mathrm{Pt}_{0.35}$ & $17.0 \mu \mathrm{mol} / \mathrm{g}(11.0 \mu \mathrm{mol} / \mathrm{g}$ of $\mathrm{Pd}+5.9 \mu \mathrm{mol} / \mathrm{g}$ of Pt $)$ \\
\hline 5 & SiNA-Pd $0.81 \mathrm{Rh}_{0.19}$ & $10.55 \mu \mathrm{mol} / \mathrm{g}(8.55 \mu \mathrm{mol} / \mathrm{g}$ of Pd $+2.0 \mu \mathrm{mol} / \mathrm{g}$ of $\mathrm{Rh})$ \\
\hline 6 & SiNA-Pd $_{0.92} \mathrm{Ru}_{0.08}$ & $7.67 \mu \mathrm{mol} / \mathrm{g}(7.02 \mu \mathrm{mol} / \mathrm{g}$ of Pd $+0.65 \mu \mathrm{mol} / \mathrm{g}$ of $\mathrm{Ru})$ \\
\hline 7 & SiNA-Pd $_{0.98} \mathrm{Ir}_{0.02}$ & $17.07 \mu \mathrm{mol} / \mathrm{g}(16.77 \mu \mathrm{mol} / \mathrm{g}$ of Pd $+0.30 \mu \mathrm{mol} / \mathrm{g}$ of $\mathrm{Ir})$ \\
\hline
\end{tabular}




\begin{tabular}{|l|l|l|}
\hline 8 & $\mathrm{Rh} / \mathrm{PSi}$ & $320 \mu \mathrm{mol} / \mathrm{g}$ \\
\hline 9 & $\mathrm{Rh} / \mathrm{Flat} \mathrm{Si}$ & $0.64 \mu \mathrm{mol} / \mathrm{g}$ \\
\hline
\end{tabular}

\section{4-2. Leaching Test of SiNA-Rh}

A leaching test for SiNA-Rh was performed to the reaction mixture in decarboxylation for stearic acid. After the fourth run of catalytic decarboxylation, the reaction mixture $(103.6 \mathrm{mg})$ was dissolved in THF (3 $\mathrm{mL}$ ) and filtered through $0.2 \mu \mathrm{m}$ PTFE syringe filter. And then, the filtrate solution was evaporated and dried under vacuum. 1.42 Ultrapure $\mathrm{HNO}_{3}(7 \mathrm{~mL})$ was added and decomposed by the microwave assisted equipment. The decomposed solution was analyzed by ICP-MS for the rhodium content.

- result: $0.019 \mathrm{ppm} \mathrm{Rh}$ inside reaction mixture $(0.0066 \%$ of $\mathrm{Rh}$ in catalyst)

\section{4-3. Hot Filtration Test}

The hot filtration in the reaction of stearic acid was carried out in $6 \mathrm{~h}$. After hot filtration, the filtrate was conducted at $200^{\circ} \mathrm{C}$ for $6 \mathrm{~h}$.

\begin{tabular}{|l|l|l|l|}
\hline Entry & 2a yield (\%) & 3a yield (\%) & $\mathrm{CO}: \mathrm{CO}_{2}$ \\
\hline 1 & 39 & 0 & $100: 0$ \\
\hline 2 (removal of catalyst) & 39 & 0 & $0: 0$ \\
\hline
\end{tabular}

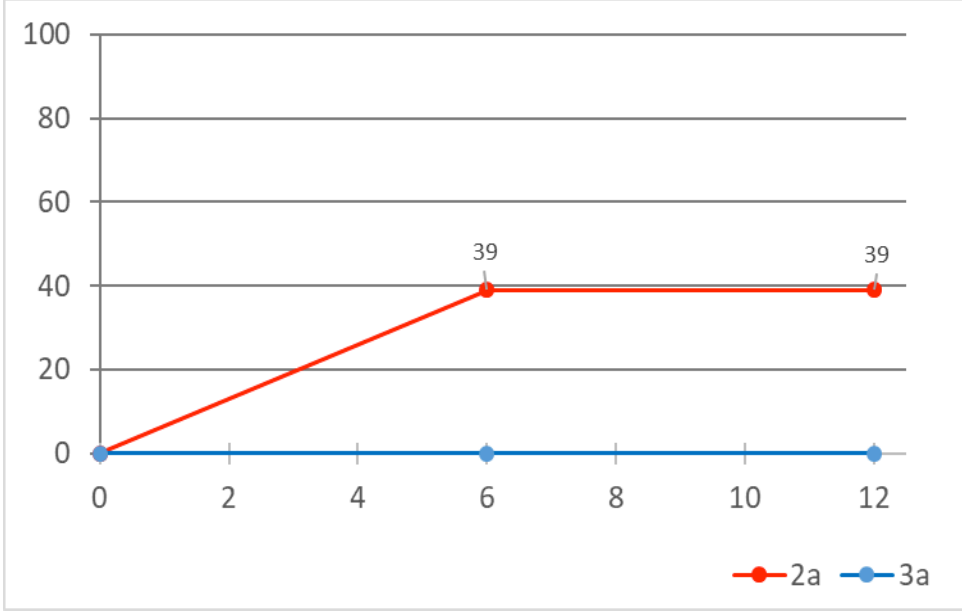




\section{General Procedure for the Decarboxylation of Carboxylic acids}

\section{Table 1.}

Stearic acid (142.3 mg, $0.5 \mathrm{mmol}$ ) and SiNA-MNPs catalyst was added in a $10 \mathrm{~mL}$ glass vessel and microwave was irradiated with $\mathrm{H}_{2}(10 \mathrm{bar})$ at $200{ }^{\circ} \mathrm{C}$ for $6 \mathrm{~h}$ (microwave irradiation: $200 \mathrm{~W}(10 \mathrm{~min})$ to $30-50 \mathrm{~W}$ (23 h $50 \mathrm{~min})$. After cooling to room temperature, a dodecane or mesitylene as an internal standard was added. The mixture $(1 \mathrm{mg})$ was dispersed in $N, N$-dimethylformamide dimethyl acetal (DMF-DMA, $0.1 \mathrm{~mL}$ ) with $\mathrm{MeOH}(0.1 \mathrm{~mL})$, heated for 30s and analyzed with GC (DB-WAX) to determine the yield.

\section{Table 2.}

Carboxylic acid $(0.5 \mathrm{mmol})$ and SiNA-Rh catalyst $(0.00025 \mathrm{mmol}, 0.05 \mathrm{~mol} \% \mathrm{Rh})$ was added to a $10 \mathrm{~mL}$ glass vessel and microwave was irradiated with $\mathrm{H}_{2}(10 \mathrm{bar})$ at $200{ }^{\circ} \mathrm{C}$ for $24 \mathrm{~h}$ (microwave irradiation: from $200 \mathrm{~W}$ to $30-50 \mathrm{~W}$ during reaction). After cooling to room temperature, a dodecane or mesitylene as an internal standard was added. The mixture $(1 \mathrm{mg})$ was dispersed in $N, N$-dimethylformamide dimethyl acetal (DMF-DMA, $0.1 \mathrm{~mL}$ ) with $\mathrm{MeOH}(0.1 \mathrm{~mL})$, heated for 30s and analyzed with GC (DB-WAX) to determine the yield. The residue was diluted with THF $(10 \mathrm{~mL})$ and purified through silica-gel column with hexane to afford the corresponding products.

\section{Catalyst Reuse Experiments}

Carboxylic acid $(0.5 \mathrm{mmol})$ and SiNA-Rh catalyst $(0.00025 \mathrm{mmol}, 0.05 \mathrm{~mol} \% \mathrm{Rh})$ was added in a $10 \mathrm{~mL}$ glass vessel and microwave was irradiated with $\mathrm{H}_{2}(10 \mathrm{bar})$ at $200{ }^{\circ} \mathrm{C}$ for $24 \mathrm{~h}$ (microwave irradiation: 200 $\mathrm{W}(10 \mathrm{~min})$ to $30-50 \mathrm{~W}(23 \mathrm{~h} 50 \mathrm{~min})$. After cooling to room temperature, a dodecane or mesitylene as an internal standard was added. The mixture $(1 \mathrm{mg})$ was dispersed in $N, N$-dimethylformamide dimethyl acetal (DMF-DMA, $0.1 \mathrm{~mL}$ ) with $\mathrm{MeOH}(0.1 \mathrm{~mL})$, heated for 30s and analyzed with GC (DB-WAX) to determine the yield. The catalyst was recovered by picking up with a tweezer and washed with EtOAc/ Acetone/Water. After drying with $\mathrm{N}_{2}$ blow, the catalyst was used for the next reaction.

\section{Catalyst Reuse Experiments with Pivalic Anhydride}


To a $10 \mathrm{~mL}$ glass vessel was added stearic acid $(142.3 \mathrm{mg}, 0.5 \mathrm{mmol})$, pivalic anhydride $(139.7 \mathrm{mg}, 0.75$ mmol) and SiNA-Rh catalyst $(0.00025 \mathrm{mmol}, 0.05 \mathrm{~mol} \% \mathrm{Rh})$. The reaction was performed with $\mathrm{H}_{2}(0.1$ $\mathrm{MPa}$ ) at $200^{\circ} \mathrm{C}$ for $24 \mathrm{~h}$ under microwave irradiation (microwave irradiation: $200 \mathrm{~W}$ (10 min) to 30-50 W (23 h $50 \mathrm{~min}$ ). After cooling to room temperature, a dodecane as an internal standard was added. The mixture $(1 \mathrm{mg}$ ) was dispersed in $N, N$-dimethylformamide dimethyl acetal (DMF-DMA, $0.1 \mathrm{~mL}$ ) with $\mathrm{MeOH}(0.1 \mathrm{~mL})$, heated for 30s and analyzed with GC (DB-WAX) to determine the yield. The catalyst was recovered by a tweezer and washed with EtOAc/ Acetone/Water. After drying with $\mathrm{N}_{2}$ blow, the catalyst was used for the next reaction.

\section{General Procedure for the Decarbonylation of an Aldehyde}

To a $15 \mathrm{~mL}$ glass vessel was added octadecanal $(134.2 \mathrm{mg}, 0.5 \mathrm{mmol})$ and SiNA-Rh catalyst $(0.00025$ mmol, $0.05 \mathrm{~mol} \% \mathrm{Rh})$. The reaction was performed with $\operatorname{Ar}(1 \mathrm{bar})$ at $150^{\circ} \mathrm{C}$ for $24 \mathrm{~h}$. After cooling to room temperature, the residue was diluted with THF $(5 \mathrm{~mL})$ and purified through silica-gel column with hexane to afford the corresponding products. The catalyst was recovered by a tweezer and washed with EtOAc/ Acetone/Water. After drying with $\mathrm{N}_{2}$ blow, the catalyst was used for the next reaction.

\section{Characterization of the Products}

${ }^{1} \mathrm{H}$ and ${ }^{13} \mathrm{C}$ NMR Data of Products

Heptadecane (2a, $>99.6 \%$ purity)<smiles>[3H]CCCCCCCCCCCCCCCC[3H]</smiles>

${ }^{1} \mathrm{H}$ NMR $\left(500 \mathrm{MHz}, \mathrm{CDCl}_{3}\right): \delta 0.87-0.89(\mathrm{t}, J=7.0 \mathrm{~Hz}, 6 \mathrm{H}), 1.26-1.31(\mathrm{~m}, 30 \mathrm{H}) ;{ }^{13} \mathrm{C} \mathrm{NMR}(125 \mathrm{MHz}$, $\left.\mathrm{CDCl}_{3}\right): \delta 14.1,22.7,29.4,29.6,29.7,31.9 ; \mathrm{MS}(\mathrm{EI}): \mathrm{m} / \mathrm{z} 240[\mathrm{M}]^{+}$.

\section{Nonadecane $(\mathbf{2 b},>\mathbf{9 8 . 5} \%$ purity $)$}

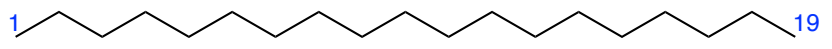

${ }^{1} \mathrm{H}$ NMR $\left(500 \mathrm{MHz}, \mathrm{CDCl}_{3}\right): \delta 0.87-0.89(\mathrm{t}, J=7.0 \mathrm{~Hz}, 6 \mathrm{H}), 1.26-1.31(\mathrm{~m}, 34 \mathrm{H}) ;{ }^{13} \mathrm{C} \mathrm{NMR}(125 \mathrm{MHz}$, $\left.\mathrm{CDCl}_{3}\right): \delta 14.1,22.7,29.4,29.6,29.7,31.9 ; \mathrm{MS}(\mathrm{EI}): \mathrm{m} / z 268[\mathrm{M}]^{+}$. 
Hexadecane (2c, $>97.0 \%$ purity)

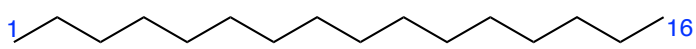

${ }^{1} \mathrm{H}$ NMR (500 MHz, $\left.\mathrm{CDCl}_{3}\right): \delta 0.87-0.89(\mathrm{t}, J=7.0 \mathrm{~Hz}, 6 \mathrm{H}), 1.26-1.32(\mathrm{~m}, 28 \mathrm{H}) ;{ }^{13} \mathrm{C} \mathrm{NMR}(125 \mathrm{MHz}$, $\left.\mathrm{CDCl}_{3}\right): \delta 14.1,22.7,29.4,29.6,29.7,31.9 ; \mathrm{MS}(\mathrm{EI}): \mathrm{m} / z 226[\mathrm{M}]^{+}$.

Pentadecane (2d, $>99.3 \%$ purity)<smiles>[13CH]CCCCCCCCCCCCCCI</smiles>

${ }^{1} \mathrm{H}$ NMR $\left(500 \mathrm{MHz}, \mathrm{CDCl}_{3}\right): \delta 0.87-0.89(\mathrm{t}, J=7.5 \mathrm{~Hz}, 6 \mathrm{H}), 1.26-1.31(\mathrm{~m}, 26 \mathrm{H}) ;{ }^{13} \mathrm{C}$ NMR $(125 \mathrm{MHz}$, $\left.\mathrm{CDCl}_{3}\right): \delta 14.1,22.7,29.4,29.6,29.7,31.9 ; \mathrm{MS}(\mathrm{EI}): \mathrm{m} / \mathrm{z} 212[\mathrm{M}]^{+}$.

\section{Tetradecane (2e, $>97.0 \%$ purity)}

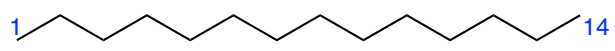

${ }^{1} \mathrm{H}$ NMR (500 MHz, CDCl $): \delta 0.86-0.89(\mathrm{t}, J=7.5 \mathrm{~Hz}, 3 \mathrm{H}), 1.26-1.30(\mathrm{~m}, 24 \mathrm{H}) ;{ }^{13} \mathrm{C} \mathrm{NMR}(125 \mathrm{MHz}$, $\left.\mathrm{CDCl}_{3}\right): \delta 14.1,22.7,29.4,29.6,29.7,31.9 ; \mathrm{MS}(\mathrm{EI}): \mathrm{m} / z 198[\mathrm{M}]^{+}$.

\section{Calculation of electromagnetic field}

A model was designed and programmed using COMSOL code (COMSOL multi-Physics ver. $5.4^{3}$ ). The model was designed to observe polariton exudes from the Silicon. The electromagnetic field distribution was solved by scattering field approximation of COMSOL. Where, Si rod: $\phi 50 \times 10000$ [nm], simulation box: $(400+\mathrm{d})^{3}\left[\mathrm{~nm}^{3}\right]$, d: distance between rods, pitch angle: $90^{\circ}$, yaw angle: $0^{\circ}$, roll angle: $0^{\circ}$, and electric field strength is $1[\mathrm{~V} / \mathrm{m}]$. As shown in FIG. s3, the periodically continuous structure of the silicon rod was reproduced by the continuous boundary condition. The electric field permeating from the silicon rod was calculated and evaluated by changing the distance between the rods. 
Incident wave: Scattering field approximation $\mathrm{E}_{0}: 1[\mathrm{~V} / \mathrm{m}]$,

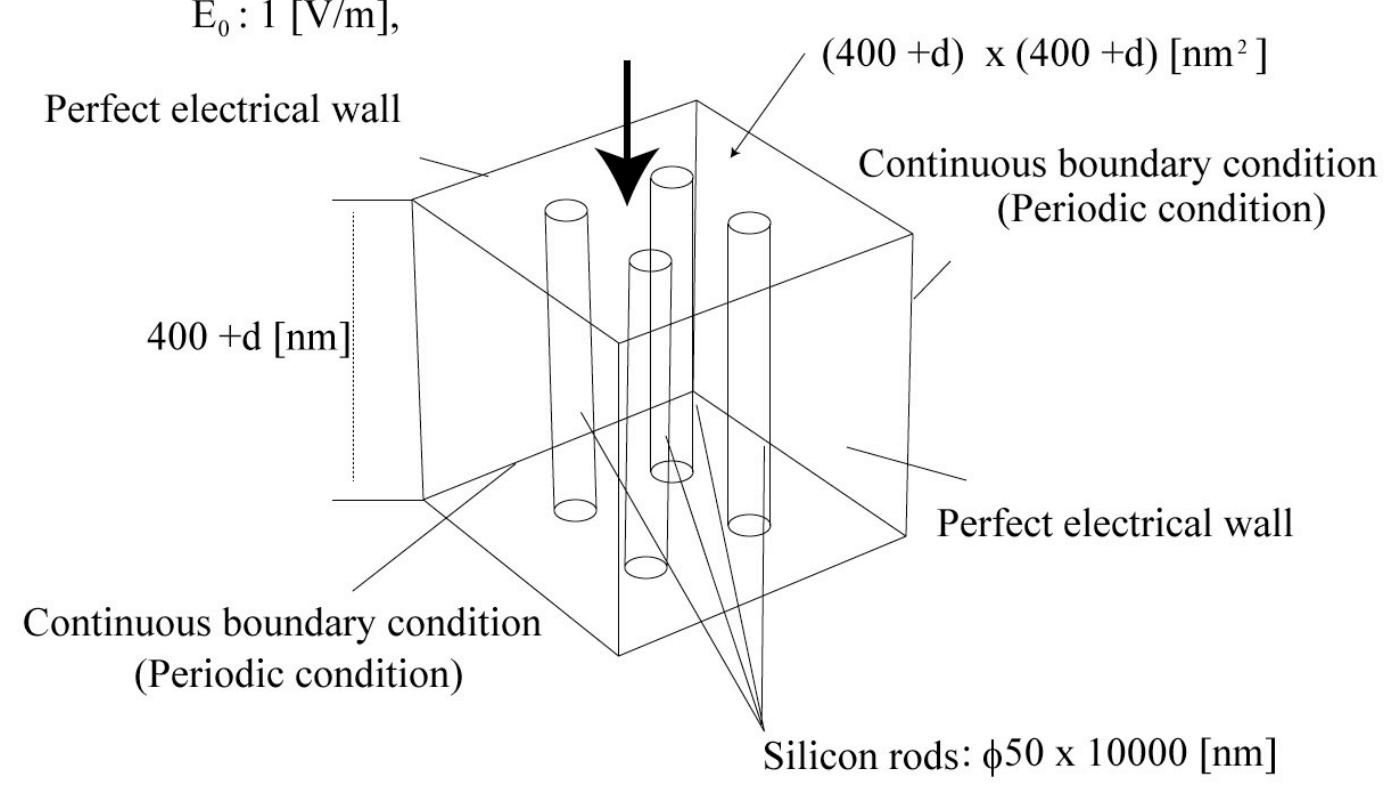

Figure S3. Boundary conditions of Numerical calculation results of electric field strength between Si rods

\section{Reference}

1. Ensafi, A. A.; Jafari-Asl, M., Rezaei, B.; Abarghoui, M.; Farrokhpour, H. Facile synthesis of PtePd@Silicon nanostructure as an advanced electrocatalyst for direct methanol fuel cells. J. Power Sources 282, 452-461 (2015).

2. Ensafi, A. A.; Abarghoui, M. M.; Rezaei, B. Facile synthesis of Pt-Cu@silicon nanostructure as a new electrocatalyst supported matrix, electrochemical detection of hydrazine and hydrogen peroxide. Electrochimica Acta 190, 199-207 (2016).

3. http://www.comsol.com/ (ACESS: 2019/1/22) 


\section{${ }^{1} \mathrm{H}$ and ${ }^{13} \mathrm{C}$ NMR spectra}
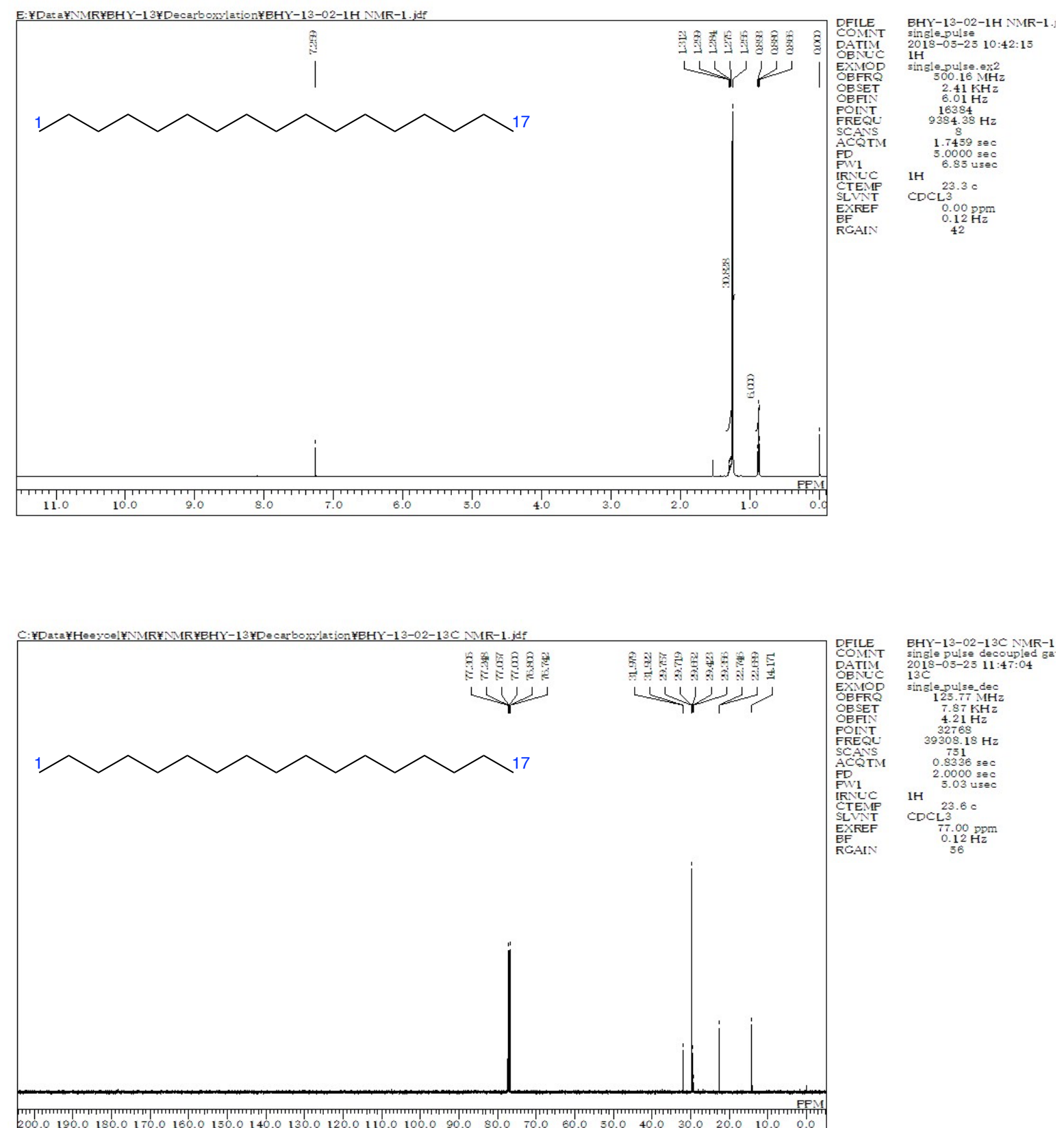

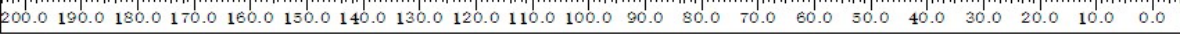



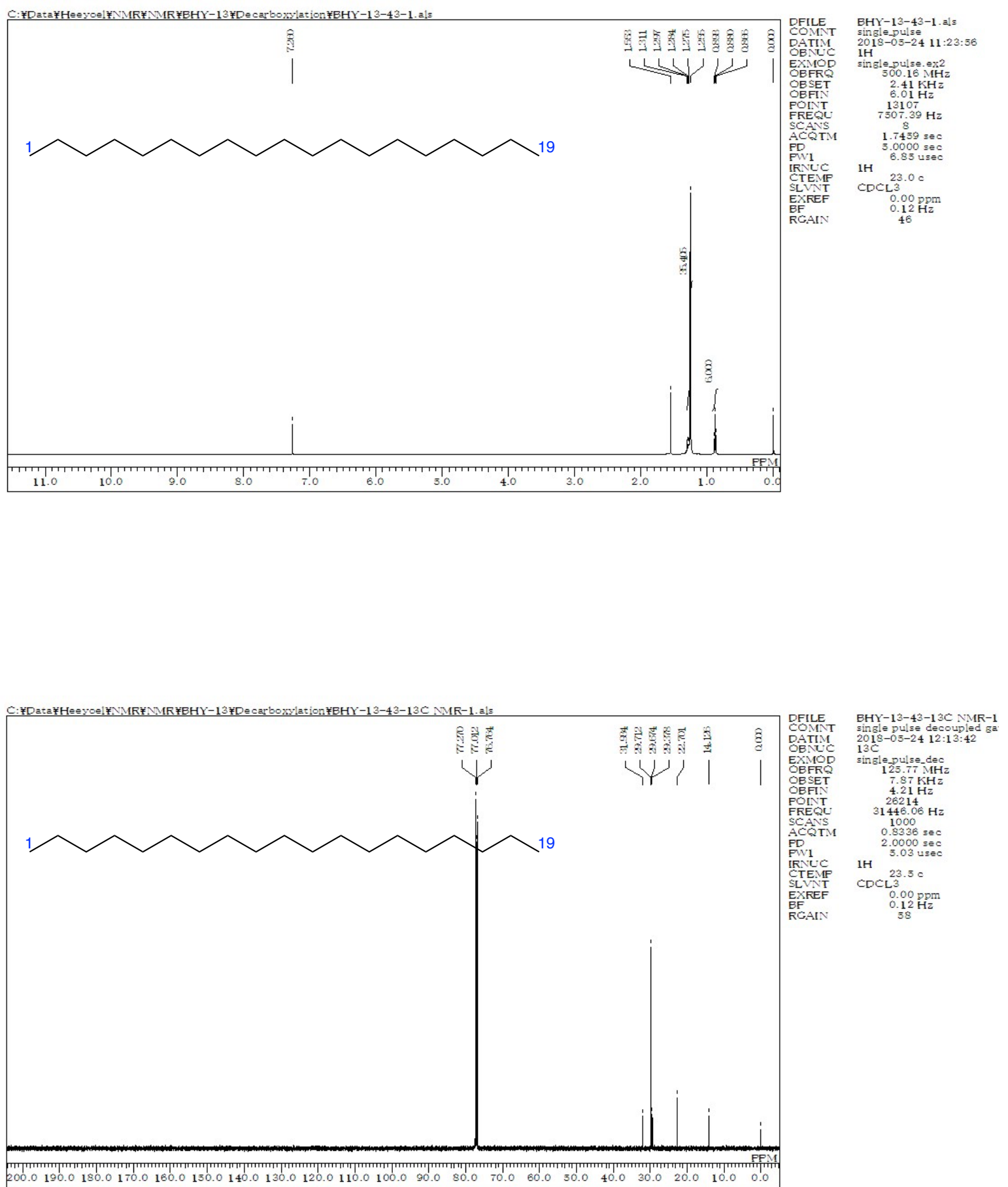

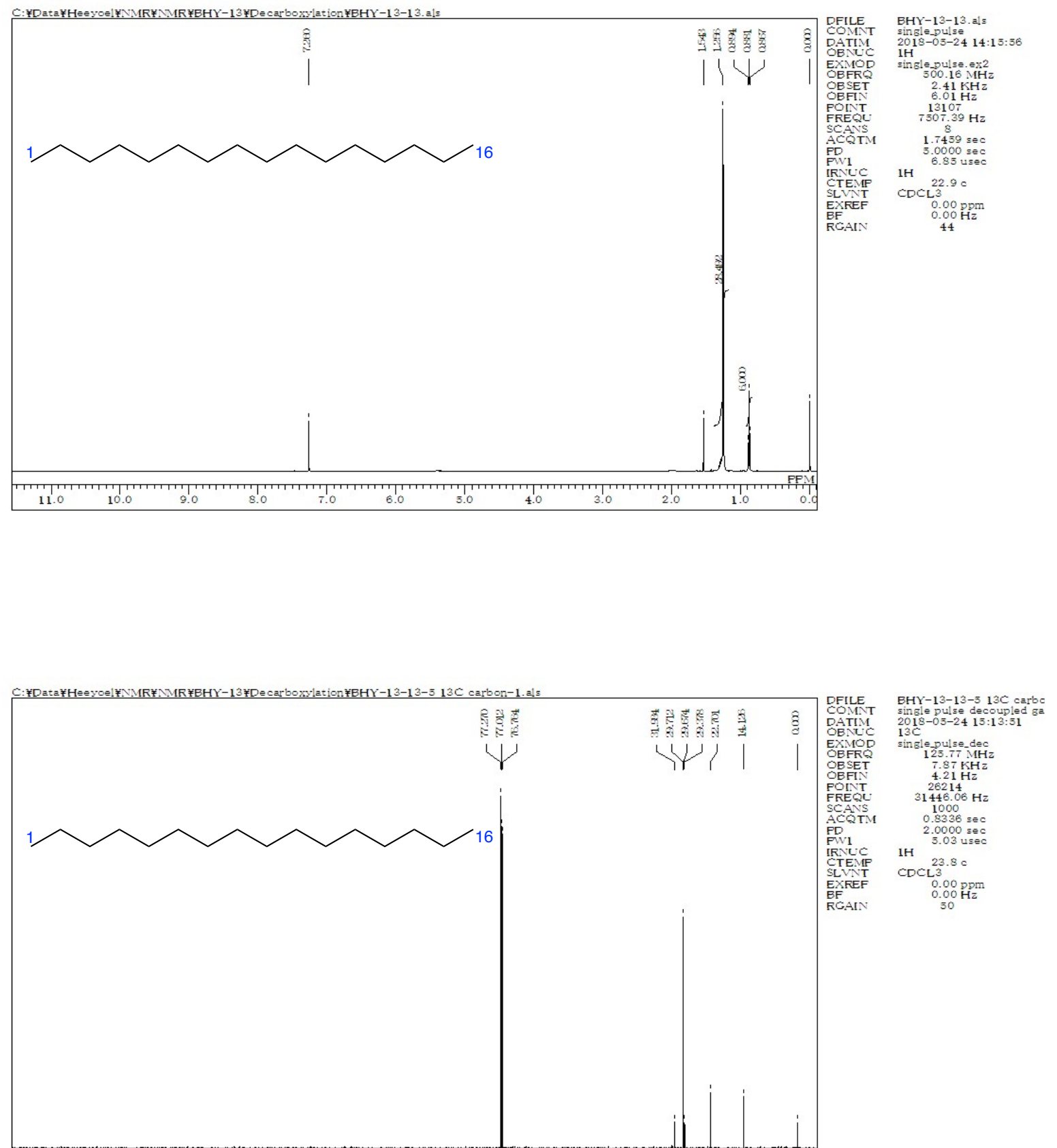

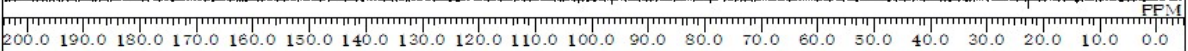



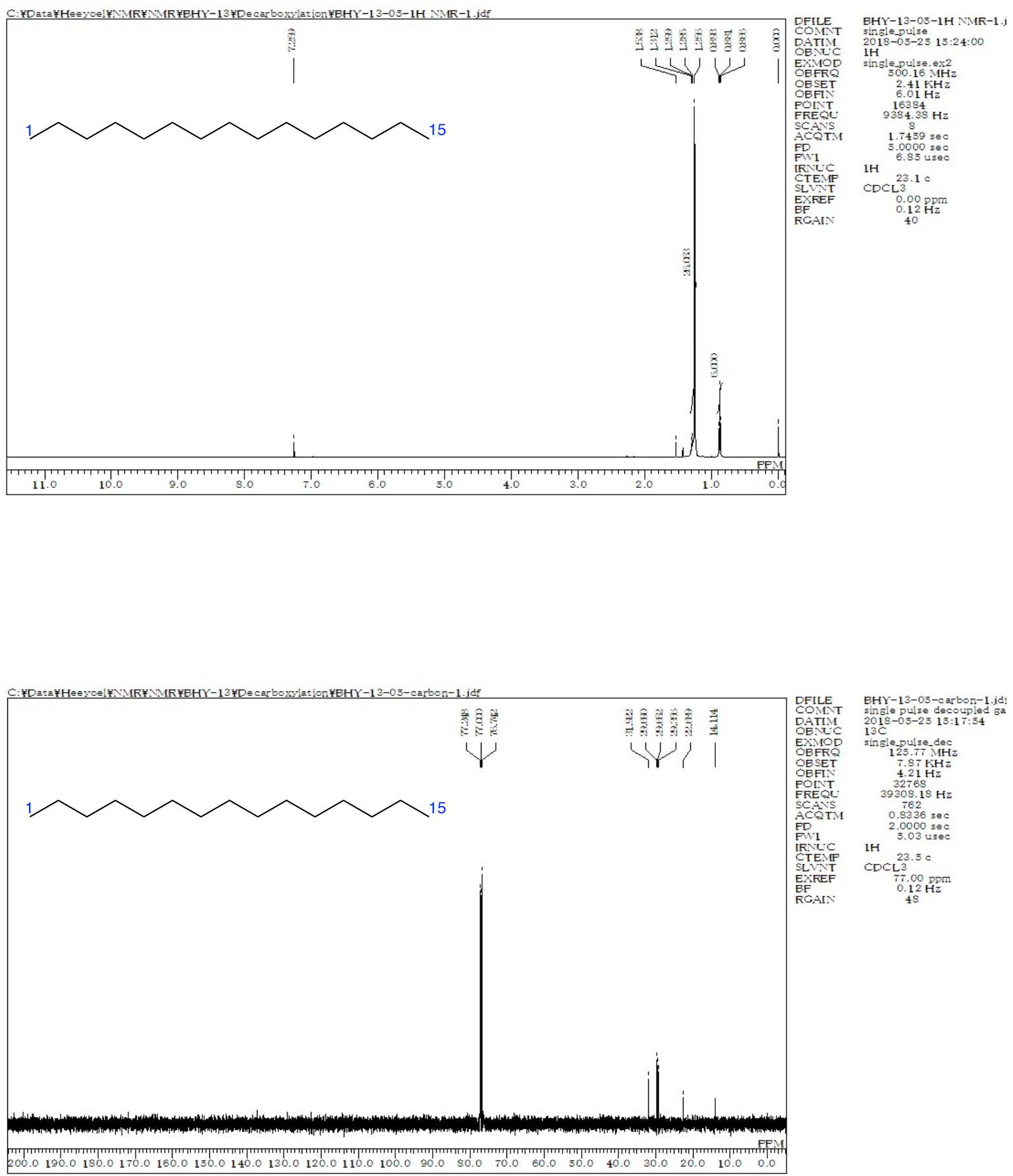

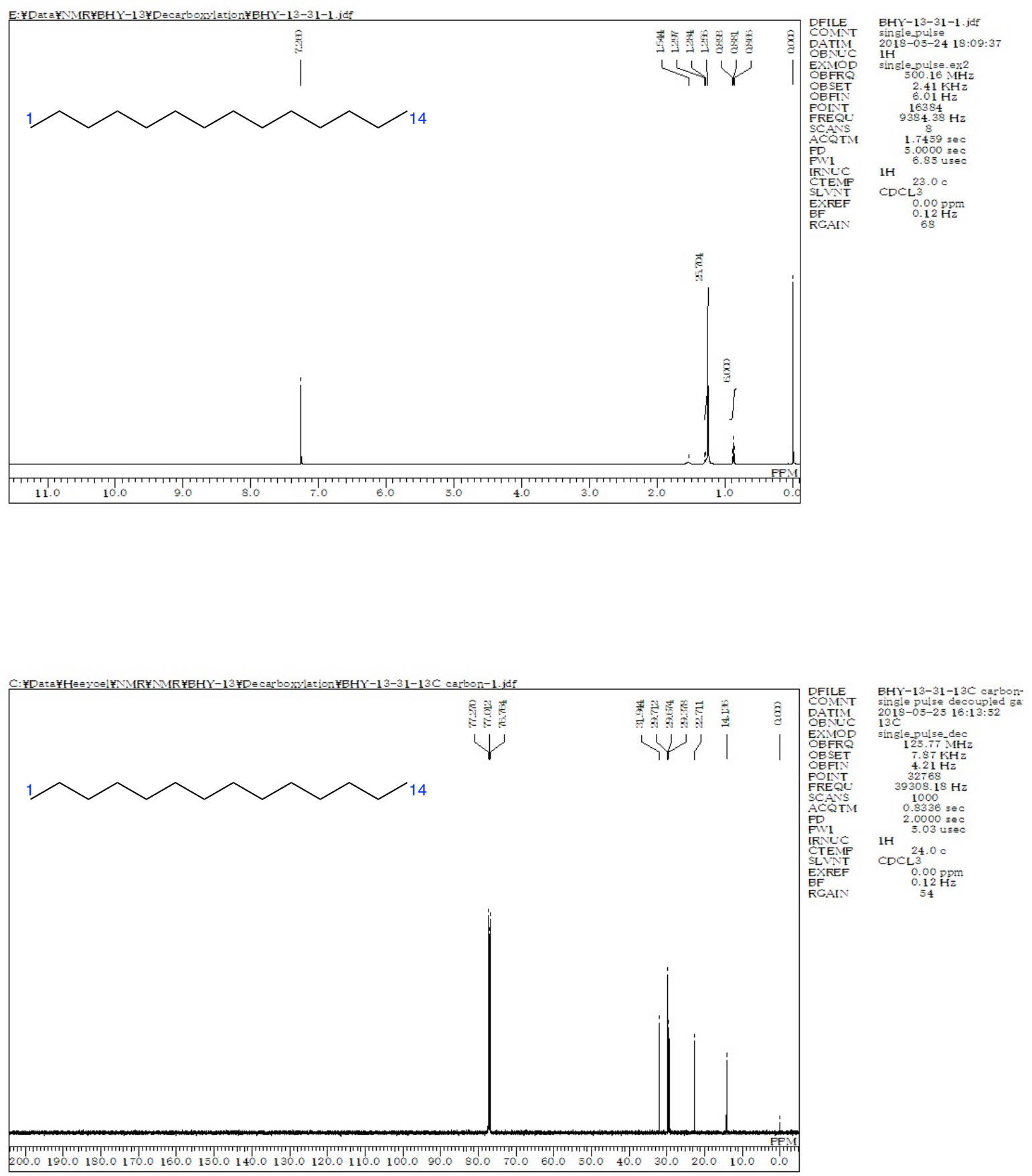